\title{
Writing the history of geography: what we have learnt - and where to go next
}

\author{
U. Wardenga \\ Leibniz Institute for Regional Geography, Leipzig, Germany \\ Correspondence to: U. Wardenga (u_wardenga@ifl-leipzig.de)
}

Received: 13 December 2012 - Revised: 7 March 2013 - Accepted: 8 March 2013 - Published: 30 May 2013

\begin{abstract}
When writing the history of geography the subject is, customarily, one's own national geography. Moreover, until the 1960 s, the discipline's history was generally told by recollecting the life and works of eminent scholars. Since then, the subject has been internationalised, owing a great deal to the IGU's commission on "History of Geographical Thought". It has also been broadened and aligned with the emerging sociology of science and later the "cultural turn"; so biographical narratives lost ground in favour of thematic studies. Nevertheless, most kept to their own national geography tradition as a frame of reference - whose development they now analysed in non-scientific contexts as well. Due to the expansion of its scope, writing the history of geography lost its exclusivity and became part of our everyday practice. Loosely following Jörn Rüsen (1982), we can distinguish three types of narration that have been employed in writing the history of geography: traditional, exemplary and critical narratives. In different ways, all three reacted to changes within geography. Changes were often perceived as crises and thus brought about attempts to stabilise identity claims through history. Currently we see a new research setting emerging that strives to overcome methodological nationalisms by means of comparative studies and analysing transfer processes. Reflecting upon one's own position is key to this concept. It results in a historiography that studies transnational patterns of the discipline's development. In doing so, it does not only find dense international networks of historical exchange relationships but also sees the researchers themselves as agents in the deconstruction of national stereotypes.
\end{abstract}

1

\section{Introduction: the sexiest subject of all}

"When no less a witness than Terry Eagleton reckons that geography 'now looks set to become the sexiest academic subject of all' we should appreciate [...] that something interesting and important has been achieved. Having surveyed this field as thoroughly as I could for a number of years, I will hazard the corollary that no part of geography is sexier at the moment than its history. No part, that is to say, is richer in raw fascination, no part is producing research more creative and interesting, and no part offers more rewarding opportunities for stimulating interaction across disciplinary boundaries" (Bassin, 2000:484).

It was Mark Bassin who so optimistically topped off a series of essays on the state of geography in the year 2000. Since 1997, he had continued the work of Thomas Glick and Felix Driver for the journal "Progress in Human Geography"
- and indeed it looked like there had been some progress made! The following essay in turn will sketch - with the subtle irony of Eagleton and Bassin - the sexiest part of the sexiest subject: the historiography of geography as a science and academic discipline.

First I will give a survey of the research done on the history of geography since the 1960s. You will see that almost until today this has been done in national frames. Nevertheless no distinct national traditions have evolved, mainly due to the high fluctuation of researchers and subjects researched. The study of the history of geography has remained open towards the theory of geography and human geography in general. Much unlike other subdivisions of our discipline, history of geography is not done by a homogeneous group of scholars who follow their own set of codified rules and claim a certain moral economy. Therefore, it does not make sense to differentiate between lay and expert historians of geography 
- a discrimination that would moreover imply that some can construct "better" or "truer" histories than others. In order to understand how concepts of history are being made, we should look at the practical work of our discipline's historians and the narratives they produce. This will be the second part of my paper. Historical narratives are not created by a chosen few. We all do so, for instance when we write an essay or apply for funding for our next research project. The narratives we thus create aim at processing our present experience; they want to reassure the subjects (that is, us) and stabilise their (our) identity claims. I will show that on a transnational scale, there are now up to three different models of historical narratives and three corresponding sets of historical concepts to go along with them.

In the third part of my essay, I would like to comment on the emerging horizons in the historiography of our discipline. Assuming that the way we write history is related to changes forced upon us in the present, I will outline ways to overcome the methodological nationalism still dominant in the study of geography's history. One possible way is comparative analyses of the transfer of scholarly concepts and ideas between (national) geographies, and I will show what insights they can give us in our practical work.

\section{An international history of geography takes shape}

Empirically, Mark Bassin was right: since the 1970s, writing the history of the discipline has become more and more popular among geographers. Especially in the Northern Hemisphere, the reform-oriented late 1960s prepared the ground for contesting notions that had formerly been taken for granted, such as the strategic and social practices geography used to produce knowledge and deliver its content. Suddenly traditional interpretations did not fit the future prospect anymore. Back then, this was felt not only by those who saw traditional moral economies crumble, but especially by young geographers. They were many - student numbers had rocketed since the 1950 s - and they saw the world very differently from their teachers.

This was fertile ground for an existential crisis of the discipline. When there is a crisis, there is a growing need for guiding interpretive paradigms. It was the heyday of theoreticians and historiographers. Already since the 1950s, the growing interest in geography's theory and methodology brought about a heightened interest in the discipline's history as well. Moreover, an astonishing number of textbooks on the history of geography were published in short sequence: Glacken's "Traces on the Rhodian Shore" (1967), Dickinson's "The makers of modern geography" (1969), James' "All possible worlds" (1972), and Dickinson's "Regional Concept: The Anglo-American Leaders" (1976). While the theory and methodology of spatial analysis opened up new perspectives, the study of geography's history aimed at maintaining the status quo, and it did so by writing the history of great white male geographers, painting the image of brilliant individuals, of ingenious professors accomplishing exemplary cognitive achievements for the furthering of science. Especially Dickinson relied on biographies and thus continued the common practice of obituaries praising the "great men" of geography. Following the motto de mortui nihil nisi bene, he painted mostly ideal careers: veni, vidi, vici. There was no room for crisis or discontinuity.

With Nietzsche (1982/1874), the histories thus established could be called "monumental" - because they emphasised the brilliant and unique, the exemplary and worthy, in order to preserve it in a forgetful present. They told heroic tales. With all due criticism, it was a fitting way of writing the history of a discipline that was centred around powerful professors and knew little of teamwork.

Consequently, when in 1968 a commission on the "History of Geographical Thought" was set up at the International Geographical Congress in New Delhi, the biographical paradigm was its methodological common ground. It enabled the diverging national schools to resort to their drawers full of obituaries and at the same time stress their national contributions to the discipline (Freeman, 1977-1987, for an overview, see Armstrong and Martin, 2000).

Yet this did not hold up for long, and neither did the expansion to writing the history of national schools and traditions (Katona, 1974; Babicz, 1980). The reason was a book that had already been published in 1962, yet took a while to catch on: Thomas S. Kuhn's "Structure of Scientific Revolutions" (1962). In the 1970s, Kuhn's book hit academic geography in Europe and North America like a bomb. The commission on the "History of Geographical Thought" reacted by organising a symposium in Edinburgh in 1977, titled "History of Geography and History of Science”, to discuss Kuhn's controversial claims (Stoddart, 1981).

Kuhn was inspired by the Polish-Jewish philosopher Ludwik Fleck, whose theory of thought collectives and thought styles dates back to the 1930s (see Fleck, 1980, 1983). For Kuhn, science does not evolve in a steadily increasing, strictly rational progress of knowledge production. Instead he showed that its way may be erratic and affected by social, political or economic factors. Thus Kuhn put the social character of science on the agenda, and this came to shake the ideas of knowledge and rationality. Now, everyone had to acknowledge that a paradigm could only be understood if its internal scholarly and external societal contexts had been duly considered. Hence there were no more universal claims in science that could have been employed to declare one scholarly interpretation more valid than another. Histories of geography that focused on inner-scientific aspects only, such as biographical narratives, all of a sudden looked very dated. As David Livingstone put it, "The preoccupation with 'great name' history and with plotting progress from an unenlightened past to a glorious present - pursuits characteristic of too much writing on the history of geography - need[ed] to 
be reassessed in the light of recent work in the history of science" (Livingstone, 1992:5).

Kuhn's assumptions were a welcome help for young geographers trying to explain the changes going on in geography. They also helped them shape their own concepts, as did David Livingstone (1979), Vincent Berdoulay (1981), Horacio Capel (1981) or Gerhard Hard (1970a, b, c, 1973, 1979), Ulrich Eisel (1980), Wolfgang Schramke (1979) and Hans-Dietrich Schultz (1980), to name just a few European protagonists. In Europe, incidentally, these major contributions came from countries that subsequently established research centres for the history of geography: in Germany at Bonn and Bochum (Hanno Beck, Manfred Büttner), in Spain at Barcelona (Horacio Capel), in France at Paris (Philippe Pinchemel, Paul Claval), in Great Britain at Edinburgh (Charles Withers) and in Ireland at Dublin (Anne Buttimer).

Since the late 1970s, the history of geography has taken firm root internationally (Hooson and Takeuchi, 1992). While preserving national aspects, the IGU commission "History of Geographical Thought" was able to raise and discuss a broad variety of issues. Yet no significant publications ensued. Only in 1988, under the general header "Academic, Official and Folk Geographies. Interplay of Local and Global Concern", was the perspective broadened systematically. The study of the history of geography now included aspects of environmental history, the relation between society and environment, and the interplay of local and global conditions in various cultures and forms of civilisation.

Now, research as well as theoretical debates went in three directions: "One pointed toward sociological and ethnographic interpretations of geographical discourse [...] the second pointed toward the interactions between nature and culture, exploring practical and even ethical aspects of applied geography. The third [...] shed light on the social construction of geographic discourse, the role of national institutions in shaping research and practice in geography, problems of representation and objectivity, and the myriad ways in which geography texts have helped shape images of places and people through history" (Buttimer, 1998:94f.). This would not have been possible without the tireless efforts of Anne Buttimer. Her keen sense of upcoming issues and her ability to win over young geographers for the commission proved vital to the project. With her as secretary as well as David Hooson and Keiichi Takeuchi as chairs, the commission edited a series of milestone volumes in the 1990s: "Geography and National Identity" (Hooson, 1994), "Geography and Imperialism" (Godlewska and Smith, 1994), "Geography and Professional Practice" (Berdoulay and van Ginkel, 1996), "Géographes au face du monde" (Robic et al., 1996), "Religion, ideology and geographical thought" (Wardenga and Wilczynski, 1998) as well as "Text and Image: Social Construction of Regional Knowledges" (Buttimer et al., 1999).
Looking at the volumes edited within the commission's framework, one cannot but notice that they attempted to adopt, each by its own right, debates from the history of science and science studies in general. This is especially true for the volumes on "Geography and National Identity", "Geography and Imperialism", and "Religion, ideology and geographical thought". Whatever it was that was hotly discussed among historians and sociologists of science, the commission and its fellow travellers tried to apply it to the history of geography. Interested historians of science were invited to join, as were historiographers of neighbouring disciplines such as social sciences, economics, and cultural and economic geography. The interdisciplinary work thus established, coupled with an increasingly self-conscious historiography of the discipline and a growing interest in theory, culminated in the volume "Text and Image". The "cultural turn" had reached the history of geography. "Text and Image" also shows clearly how writing the history of science can be a gateway for the reception of relational approaches.

By the end of the 1990s at the latest, the study of the history of geography had thus caught up with the current research standards as well as with history and sociology of science in general. Moreover, it was on its way to becoming an intellectually fascinating field of research. This came to be, paradoxically, because the commission was not working in a self-contained manner to form an international group of experts on the subject. On the contrary, it remained open for the contribution of scholars who only occasionally dealt with the history of geography. From this resulted a very lively debate, invigorated by contacts with other subdivisions of human geography, especially those that discussed the approaches that we now call the cultural turn (see Bachmann-Medick, 2006). Yet amid the jubilant reviews penned by heads of commissions, we have to face the fact that with more than 300 members from 52 countries (Buttimer, 1998:98, fn 5) most essays had a national frame of reference. Nevertheless, no national traditions evolved in writing the history of geography, neither in the methodological approaches nor in the subjects dealt with. The fluctuation of researchers involved was simply too high, and the range of subjects too broad. This had two positive effects: first of all, research horizons have always been open, without attempts at reducing them to an authoritative perspective. Secondly, the practice of history writing has not been limited to a few experts, but has been done by many. Thus the question arises how and for what purposes histories of geography are being written.

\section{Types of historical narration}

In geography, narrating the history of the discipline is much more widespread than we would expect. As a matter of fact, it is very much part of our everyday practice. Geographers tend to construct and convey their knowledge on the history of the subject when trying to introduce newcomers to the trade. 
Summing up recent research, any introduction to a study or application for funding includes aspects of the history of geography. Even innovative studies that question conventional methods of geography tackle aspects of its history - because they want to stress how very innovative the proposed approach is compared to a presumably outdated method. I wholeheartedly agree with Hans Ulrich Gumbrecht (1982), who, for good reasons, argued that historical narrations, being omnipresent and elemental, are definitely one of the fundamental functions of the world we live in.

Thus, the focus is on the praxeology and ultimately on how histories of geography are generated. Jörn Rüsen (1982) pointed out that the potential of memory is mobilised and put to use specifically when present experiences no longer fit into interpretative patterns of the past. New interpretative patterns have to be found that comply better with recent experience. This serves the purpose of self-affirmation as well as stabilising and implementing our claims of identity. This goes a long way to explain two findings. First, it elucidates why the history of science flowers especially in times of crisis, or when new research approaches are to be implemented. Second, it makes clear why there are so few coherent images on national or international levels but rather a hotchpotch of various interpretations of history, which confuses many a student.

According to Rüsen (1982), historical memory is conveyed in four different types of narration. These types can be found more or less in any historical narrative, but may be distributed unevenly and in varying degrees of importance. To keep things short, I will sketch out just the three types that have been - up to now - most prominent in geography. They can be found over and over again in geography in the last $150 \mathrm{yr}$. The interesting thing about Rüsen's concept is that it allows us to take a thorough look into social situations in which and for which history is functionalised. While perusing my little typology, I encourage readers to consult their own experience - be it in reading or otherwise. I am sure that one thing or the other will ring a bell.

"Traditional narratives" are used mostly when a particular perspective is in danger of becoming outdated. All over the Western world, traditional narrations are employed by authors who wish to add dignity to a particular perspective by elaborating on its longevity. They look for well-respected antecedents in order to claim that these forefathers, back then less exact and less clearly, had basically the same ideas that one's own research sheds new light upon now. Alfred Hettner's rendition of Ritter's and Richthofen's concepts is a perfect example of this strategy (Hettner, 1898, 1927). Here, these authors appear to be forerunners of Hettner's own concept of geography, turning it into the ultimate fulfilment of what the founding fathers presumably intended (see Wardenga, 1995). Another fine example is the works of Richard Hartshorne (1939, 1958), who interpreted Hettner's concept in light of the landscape geography of the interwar years (see Harvey and Wardenga, 2006), or the textbooks by Dickinson mentioned earlier. This type of historical narrative is meant to stabilise the subject's identity and implement his or her theories by referring to accepted authorities. To put it less respectfully, authors lend from other people's reputation in order to not have to rely on their own. Traditional narratives were thus employed on an international level to underline the significance and reputation of geography by presenting it as a stronghold of continuous scientific progress in knowledge generation.

The second type is the "exemplary narrative". This is the preferred mode when it is dawning on the representatives of a mainstream approach that their method is about to go down in history itself. They react to that threat by searching sets of basic and abstract rules in the historic field of their respective approach. They want to thereby prove the lasting productivity of their approach as well as its enduring validity, irrespective of ongoing methodological changes. Many papers in the German-speaking countries on the controversy over regional studies (Länderkunde) and landscape studies (Landschaftskunde) use this type of narrative. The best-known is Eugen Wirth's much-quoted essay "Zwölf Thesen zur aktuellen Problematik der Länderkunde" (Twelve Theses on Current Problems in Regional Geography), his reaction to students' criticism at the German Geographers' National Meeting (Geographentag) at Kiel in 1969 (Wirth, 1970). While Wirth did not deny the need for reform, he insisted on the validity of traditional Länderkunde methods, like field observation, mapping, interviews and other sources. For him, these implicit rules of research guaranteed results that were "true" knowledge. He thus advocated the expertise of trained regional geographers. "Journalism-style snapshots", Wirth argued, could not replace the old Länderkunde and its aim of critically informed expert creation of relevant societal knowledge.

Exemplary narration is also frequently used by physical geographers who write about "integrative projects" in geography. In a renewed debate on chances and limits of integrated research, exemplary narratives strive to tell us that traditional geography is the most competent discipline for researching relations between man and the environment. They thus hope to reduce the gap that has been growing between human and physical geography since the 1970s (cf. Ehlers and Leser, 2002; Leser, 2003; Ehlers, 2005). Margarita Bowen (1981) takes the same line by analysing rules of empirical research from Bacon to Humboldt - to ultimately draw fresh ideas for environmental research inspired by authorities like Humboldt.

Last but not least there is a third type, the "critical narrative". In the anglophone world of geography, this type came to the fore in the 1970s, with classic antecedents like Fred K. Schaefer's epoch-making "Exceptionalism in Geography" (1953). Critical narratives bring forth stories on geography aiming at the deconstruction of accepted notions of continuity. Thus, what is narrated is mostly anti-stories, and the narrators are often young scientists at the beginning of their 
careers. These are strongly influenced by the experience - an experience that can also be used to further a career - that existing patterns of interpretation do not grant orientation for the present and the future anymore. As I see it, critical narrative is employed within international geography mostly in order to support new perspectives on an old field of research, or to put forward new fields of research. Thus, critical narrative aims mainly at convincingly conveying the capability to change norms. In my opinion, there is no need to elaborate on examples of critical narrative; suffice it to mention the key words "New Regional Geography" (e.g. Wood, 1996), "New Cultural Geography" (Cosgrove, 1985; Cosgrove and Jackson, 1987; Duncan, 1980; Philo, 1991; Mitchell, 1995; Gebhardt et al., 2003; Natter and Wardenga, 2003), "Critic Geopolitics" (Wolkersdorfer, 2001; for a critical perspective see Redepenning, 2006) or "Critical Cartography" (Harley, 1989; Crampton, 2001; Crampton and Krygier, 2005; Dodge et al., 2011:2-7; an overall review in Edney, 2012).

This type of narrative, much more pronouncedly than the ones I mentioned first, has the potential to be turned into a weapon when a scientific community, ignorant of its history, is fixated on the latest "turns" and trends of the trade - to enforce the validity of their own approaches. The authors who tell this type of narrative often claim high moral standards, thus blurring the boundaries of history of science and politics of science. A good example for this way of writing history is the "Map Reader" edited by Dodge et al. (2011). In his comprehensive review, Matthew H. Edney rightly criticised their selective choice of readings as "uncritical understanding of cartographical history" (Edney, 2012:66), "historical distortion" and "mistreatment" of texts (67), all of which ultimately perpetuate "long established disciplinary ideologies" (67).

\section{Emerging horizons of future research: histories of transfers and connectedness}

As I said in my little outline of the history of writing the history of the "sexiest subject of all", by the 1990s at the latest, historians of geography had caught up with the scholarly debates around them. We know where we stand now. Yet where do we want to go from here?

Over the last years, traditional boundaries of scholarly disciplines and national schools have eroded and become questionable. Internationalisation of academia, but also the emergence of new fields of study - global studies, urban studies, development studies, to name just a few - have greatly influenced the way we organise research today. Any cutting-edge historiography must accommodate these developments. We can no longer base our research on a taken-for-granted nation state as space of reference, as by doing so we risk explaining the history of "our" geography mostly based on national developments, ignoring factors beyond national boundaries. Attempts at bridging the transnational gap in an internation- alised historiography of geography - as documented in the volumes of the IGU commission - are not sufficient anymore. It is rather imperative to analyse transnational exchange processes.

The emerging Global History with its focus on transnational exchange (e.g. Middell and Naumann, 2010) has pointed out and discussed deficits in historiography. Especially comparative approaches have been subject to scrutiny. These reflections resulted in theoretically informed approaches such as transferts culturels by Michel Espagne (2002), "entangled history" by Sebastian Conrad et al. (2002) or histoire croisée, developed by Michael Werner and Bénédicte Zimmermann (2002, 2006).

I would like to share some findings of an ongoing GermanFrench project, initially funded by DAAD and Égide, and supported with travel grants by the German-French University. In this project, a joint research group of the Leibniz Institute for Regional Geography and French CNRS-Equipe E.H.GO UMR 8504 has analysed the exchange processes between German and French geography in the 19th and 20th centuries. We had a closer look at mutual references in theory, methodology and practical research, making use of Werner and Zimmermann's concept of histoire croisée (Werner and Zimmermann, 2006). This concept is special because, borrowing from science studies, it stresses the reflexive character of research and tries to stimulate scrutiny of our own subliminal concepts by methodological means in a transnational research framework.

In the context of histoire croisée, there are three methodological aspects that are crucial for a successful comparative analysis (according to Werner and Zimmermann, 2006):

1. The dangers of an external observer: transnational comparison often follows the patterns of cognitive observation, usually based on differences and similarities. The main methodological danger with this is to implicitly adopt the viewpoint of an external observer and thus compare the objects of interest from an outsider's perspective. As our perception is shaped by socialisation, learnt experience and implicit knowledge, it often unnoticeably influences the research process. Especially when doing transnational research we must keep this in mind if we want to escape the dangers of self-referential loops and related prejudices.

2. Contexts, complex variety and multi-perspectivity: transnational comparison and trans-disciplinary practice are often based on (re)constructing external contexts. Usually we project our own experience and world view onto experiences and world views of others. It is therefore crucial to analyse the contexts of the agents in question very carefully. The complex variety and multiperspectivity thus emerging within the research process can pose serious methodological problems, especially as we tend to create coherent and rigorous historical narrations. 
3. Dangers of Reification: yet another problem of comparative studies is that the items compared are often thought of as static entities. Consequently all transnational endeavours run the risk of being designed within the reference space of the nation state. This might lead to the teleological idea of diffusion as a threestep process of introduction, transmission and reception. Even more important is what Werner and Zimmermann (2006:38) stated on comparison: "Entities and objects of research are not merely considered in relation to one another, but also through one another, in terms of relationships, interactions, and circulation. The active and dynamic principle of the intersection is fundamental in contrast to the static framework of a comparative approach that tends to immobilize objects".

In view of these assumptions, one fact becomes clear: this way of doing research is rather slow and meticulous. As such, it is likely to collide with neoliberal ideas of making scholarly research marketable and more readily available. Yet and this I can say with reasonable certainty - it really pays off in the end. It makes us aware of our own position and disposition in the research process and thus lets us understand to what enormous degree (national) taken-for-granted stereotypes and structures shape our historiography.

What have we learnt so far? I would like to highlight three aspects in order to illustrate the methodological caveats outlined above.

First and foremost, we realised that writing the history of a discipline, when done in the customary national categories, tends to consider its own settings as absolute, simply because they are the normal condition. It is what we know, have grown up with, have been taught by our teachers. This concerns what we research into, how we research and even who we research with. In our project we came to understand that this "insider perspective" can lead to severe misinterpretations - regarding the history of the "foreign" geography on the one side, but much more regarding the history of one's own geography on the other side. So, for example, when we analysed the concept of Landschaft, we did not succeed in fitting it into a set of abstract criteria that would enable a sound (transnational) comparison. It was simply charged with too much implicit (national) knowledge that we had not been aware of (see Hallair, 2010). This paradoxical phenomenon is caused by blind spots that prevail even in the most differentiated types of historical narratives. In our project, German historians of geography learnt to see things through the eyes of their French colleagues, realising, e.g., how massively the federal set-up of the German nation state has shaped the structure of German geography. So the permanent competition of universities and geographical institutions of the various Länder (federal states) led to a cacophonous mass of methodological texts, duly analysed by Hans-Dietrich Schultz (1980) in what still makes an excellent read today.
We have also learnt to keep an eye on shifting contexts. Take Friedrich Ratzel (1844-1904) who, during his lifetime, was an outsider to German geography. His colleagues, with their minds fixed on geomorphology, found his bulky books so hard to read that they had to break them down in lengthy reviews. Yet in France, Ratzel was deemed the most important scholar of the German regional and human geography tradition. At our binational project meetings, our colleague Marie-Claire Robic explained us how Ratzel then turned, slowly but surely, from a scholarly hero into an anti-figure when French geography made him an adversary of the ever more estimated Paul Vidal de la Blache (1845-1918). In Germany, on the contrary, it needed several rounds of reinterpretation to bring Ratzel back on the agenda for good, not least inspired by French géographie humaine.

Thirdly, our research group learnt that, even when analysing knowledge transfer processes, the danger of reification is always imminent. When we studied the development of 19th-century geomorphology as a German-French histoire croisée, we realised that this cannot be understood without the English-speaking discussion in geology and geomorphology at that time. The Harvard geomorphologist William Morris Davis (1850-1934) and his "Cycle of Erosion" theory played an eminent role in the emerging international geographic debate after 1900. This remarkably transnational process of knowledge exchange before World War I was not only an example of mutual recognition of academic writings. It actually occurred in direct contact when Davis travelled Europe and joint field trips of European and American geographers traversed various parts of the globe together. In social and scholarly contact and by debating his cycle theory, a complex variety of international exchange processes evolved, creating interactions that even overlapped within a single national frame.

Consequently, along paradigms of studying and explaining landscape that differed in the various scholarly and national cultures, distinct transnational structures of geomorphology research emerged, which shaped the discipline well into the 20th century.

Based on the reflections of histoire croisée, the examples I briefly sketched hint at the fact that the changes inflicted upon us by the present age cannot be adequately described anymore with the three types of narratives outlined above. Rather, we need what Rüsen (1987:92-94) termed "genetical narratives". This type of narration tells stories "in which the alteration of forms of life is necessary for their permanence". The "forces of change" are thus represented as "factors of steadiness". Genetical narratives moreover "organise human self-understanding as a temporally dynamic process: time gains the sense of temporality" and "form identity by mediating permanence and change to a process of self-definition (in German this is called 'Bildung')". And Bildung - which in German can mean both creation and learning - means being ready to learn, having a critical perspective on the self, 
self-aware and self-reflective - always conscious of the fact that all knowledge is temporary and tentative.

\section{Conclusion: what we have learnt and where to go next}

When I outlined the history of writing the history of geography, I identified four distinct stages of development. The earliest sprung from the practice of writing obituaries and eulogies and was based on biographical narratives. With clear national reference, it recollected the history of the discipline as a history of "great men". When geography became more and more international in the 1970s, this practice met with increasing criticism, especially when the sociology of science came to the fore. The changing relation between geography and society and the social construction of space became important subject matters, too.

The great variety of subjects and the fluctuation of scholars involved did not give rise to national schools or styles of writing the history of geography. Nevertheless we can distinguish various transnational types of historical narratives: traditional, exemplary and critical. They all react to the challenges of change that our present age imposes upon us. By narration, they try to cope with a type of change that often feels like crisis. They create a great variety of historical imaginaries that might even contradict each other, and none of which could claim to be "true", "right" or the only possible interpretation. Since the 1970s, critical narratives have become the preferred mode of writing the history of geography, which deserves special attention. They seem to be - on the one hand - a reaction to the "turns" and trends that have come to replace each other in increasingly accelerated cycles. Thus in human geography it seems necessary to create anti-stories that make room for new and innovative developments within the scope of a rising theoretical and methodological cosmopolitanisation. On the other hand, critical narratives make the limits of historiography of scholarly disciplines more and more permeable towards the politics of the discipline, because this way of producing historical narratives tends to turn its interpretation into a weapon to enforce concepts and ideas currently in vogue. Thus historiography tacitly turns into a practice of power: the past is colonised by a present perspective. Yet for the future we need concepts that enable us to critically reflect upon the act of narrating history. Concepts that enable us, when we draw a methodologically controlled comparison in our research, to avoid both the problems of an external observer and the dangers of reification. This means, firstly, a close scrutiny of historical contexts. It also means learning to deal with complex variety and multi-perspectivity. And it means letting go of the methodological nationalism that historians of geography have cultivated for so long. Instead, we should rather analyse the transnational and transcontinental transfers of ideas and concepts. When the ideas that later turned into this essay were first presented at Fribourg, Benedikt Korf, who had the kindness to read them in lieu of the absentee author, commented very much to the point: "When we manage to go beyond national frames of historical narration, and by noticing the social construction of boundaries between so-called 'national traditions', we can only start to make such boundaries permeable. We can try to make them connecting rather than separating, not only in research about the history of geography, but in all narrations that mobilise histories of the subject in their everyday practices of making academic geographies". This holds true now even more than ever.

Translated by Jutta Faehndrich

Edited by: B. Korf

Reviewed by: two anonymous referees

\section{References}

Armstrong, P. H. and Martin, G. J.: Geographers: biobibliographical studies 1977-2000, Geogr. Rev., 90, 256-259, 2000.

Babicz, J. (Ed.): Les écoles géographiques, PWN - Polish Scientific Publishers, Warsaw, 1980.

Bassin, M.: Studying ourselves: history and philosophy of geography, Prog. Hum. Geog., 24, 475-487, 2000.

Bachmann-Medick, D.: Cultural Turns. Neuorientierungen in den Kulturwissenschaften, Rowohlt, Reinbek, 2006.

Berdoulay, V.: La formation de l'école de géographie (1870-1914), Comité des travaux historiques et scientifiques - CTHS, Paris, 1981.

Berdoulay, V. and van Ginkel, H. A. (Eds.): Geography and professional practice, Koninklijk Nederlands Aardrijkskundig Genootschap, Utrecht, 1996.

Bowen, M.: Empiricism and geographical thought. From Francis Bacon to Alexander von Humboldt, Cambridge University Press, Cambridge, 1981.

Buttimer, A.: Geography's contested stories: changing states-of-theart, Tijdschr. Econ. Soc. Ge., 89, 90-99, 1998.

Buttimer, A., Brunn, S. D., and Wardenga, U. (Eds.): Text and Image. Social Construction of Regional Knowledges, Institut für Länderkunde, Leipzig, 1999.

Capel, H.: Filosofía y ciencia en la Geografía contemporánea: una introducción a la Geografía, Barcanova, Barcelona, 1981.

Conrad, S., Randeria, S., and Römhild, R. (Eds.): Jenseits des Eurozentrismus. Postkoloniale Perspektiven in den Geschichts- und Kulturwissenschaften, Campus, Frankfurt am Main, 2002.

Cosgrove, D.: Prospect, perspective and the evolution of the landscape idea, T. I. Brit. Geogr., New Series, 10, 45-62, 1985.

Cosgrove, D. and Jackson P.: New directions in cultural geography, Area, 19, 95-101, 1987.

Crampton, J. W.: Maps as social constructions: power, communication and visualisation, Prog. Hum. Geog., 25, 235-252, 2001.

Crampton, J. W. and Krygier, J.: An introduction to critical cartography, ACME, 4, 11-33, 2005. 
Dickinson, R. E.: The makers of modern geography, Frederick A. Praeger, New York, 1969.

Dickinson, R. E.: Regional concept: the Anglo-American leaders, Routledge \& Kegan Paul, London, 1976.

Dodge, M., Kitchin, R., and Perkins, C. (Eds.): The map reader: theories of mapping practice and cartographic representation, Wiley-Blackwell, Chichester, 2011.

Duncan, J. S.: The superorganic in American cultural geography, Ann. Assoc. Am. Geogr., 70, 181-198, 1980.

Edney, M. H.: Plus ça change: defining academic cartography for the twenty-first century, Cartographica, 47, 64-69, 2012.

Ehlers, E.: Mensch-Umwelt-Beziehungen als geographisches Paradigma, in: Allgemeine Anthropogeographie, edited by: Schenk, W. and Schliephake, K., Ernst Klett, Gotha and Stuttgart, 769-783, 2005.

Ehlers, E. and Leser, H.: Geographie heute - für eine Welt von morgen, Ernst Klett, Gotha and Stuttgart, 9-18, 2002.

Eisel, U.: Die Entwicklung der Anthropogeographie von einer "Raumwissenschaft" zur Gesellschaftswissenschaft, Kasseler Schriften zur Geographie und Planung, Kassel, 1980.

Espagne, M.: Au delà du comparatisme, in: Espagne, M.: Les transferts culturels franco-allemands, Presses Universitaires de France, Paris, 35-49, 2002.

Fleck, L.: Entstehung und Entwicklung einer wissenschaftlichen Tatsache. Einführung in die Lehre vom Denkstil und Denkkollektiv. Mit einer Einleitung herausgegeben von L. Schäfer und Th. Schnelle, Suhrkamp, Frankfurt am Main, 1980.

Fleck, L.: Erfahrung und Tatsache. Gesammelte Aufsätze. Mit einer Einleitung herausgegeben von L. Schäfer und Th. Schnelle, Suhrkamp, Frankfurt am Main, 1983.

Freeman, T. W. (Ed.): Geographers. Bio-bibliographical studies, Mansell, London, 1977-1987.

Gebhardt, H., Reuber, P., and Wolkersdorfer, G. (Eds.): Kulturgeographie. Aktuelle Ansätze und Entwicklungen, Spektrum Akademischer Verlag, Heidelberg and Berlin, 2003.

Glacken, C. J.: Traces on the Rhodian shore. Nature and culture in western thought from ancient times to the end of the eighteenth century, University of California Press, Berkeley and Los Angeles, 1967.

Godlewska, A. and Smith, N. (Eds.): Geography and Imperialism, Blackwell, Oxford, 1994.

Gumbrecht, H. U.: "Das in vergangenen Zeiten Gewesene so gut erzählen, als ob es in der eigenen Welt wäre". Versuch zur Anthropologie der Geschichtsschreibung, in: Formen der Geschichtsschreibung, edited by: Koselleck, R., Lutz, H., and Rüsen, J., dtv, München, 480-513, 1982.

Hallair, G.: Histoire croisée entre les géographes français et allemands de la première moitié du XXe siècle: la géographie du paysage (Landschaftskunde) en question, Ph.D. thesis, Universities Paris I Panthéon-Sorbonne and Leipzig, available at: http: //nbn-resolving.de/urn:nbn:de:bsz:15-qucosa-64798, 2010.

Hard, G.: Die "Landschaft" der Sprache und die "Landschaft" der Geographen, Ferd. Dümmler, Bonn, 1970a.

Hard, G.: Was ist eine Landschaft?, in: Wirtschafts- und Sozialgeographie, edited by: Bartels, D., Kiepenheuer und Witsch, Köln and Berlin, 66-84, 1970b.

Hard, G.: Noch einmal: "Landschaft als objektivierter Geist". Zur Herkunft und forschungslogischen Analyse eines Gedankens, Erde, 101, 171-197, 1970c.
Hard, G.: Die Geographie. Eine wissenschaftstheoretische Einführung, de Gruyter, Berlin and New York, 1973.

Hard, G.: Die Disziplin der Weißwäscher. Über Genese und Funktion des Opportunismus in der Geographie, in: Zur Situation der deutschen Geographie zehn Jahre nach Kiel, edited by: Sedlacek, P., Selbstverlag des Fachbereichs 2 der Universität Osnabrück, Osnabrück, 11-44, 1979.

Harley, J. B.: Deconstructing the map, Cartographica, 26, 1-20, 1989.

Hartshorne, R.: The nature of geography: a critical survey of current thought in the light of the past, Association of American Geographers, Lancaster, Penn., 1939.

Hartshorne, R.: The concept of geography as a science of space, from Kant and Humboldt to Hettner, Ann. Ass. Am. Geogr., 48, 97-108, 1958.

Harvey, F. and Wardenga, U.: Richard Hartshorne's adaption of Alfred Hettner's system of geography, J. Hist. Geogr., 32, 422-440, 2006.

Hettner, A.: Die Entwicklung der Geographie im 19. Jahrhundert, Rede, gehalten beim Antritt der geographischen Professur an der Universität Tübingen am 28.4.1898, Geogr. Z., 4, 305-320, 1898.

Hettner, A.: Die Geographie. Ihre Geschichte, ihr Wesen und ihre Methoden, Ferdinand Hirt, Breslau, 1927.

Hooson, D. (Ed.): Geography and national identity, Blackwell, Oxford, 1994.

Hooson, D. and Takeuchi, K.: The IGU Commission on the History of Geographical Thought, GeoJournal, 26, 216-217, 1992.

James, P. E.: All possible worlds. A history of geographical ideas, The Odyssey Press, Indianapolis and New York, 1972.

Katona, S. (Ed.): La naissance de la géographie humaine: Friedrich Ratzel - Paul Vidal de la Blache, Académie des Sciences de Hongrie, Budapest, 1974.

Kish, G. (Ed.): Bibliography of international geographical congresses 1871-1976, G. K. Hall, Boston, 1979.

Leser, H.: Geographie als Integrative Umweltwissenschaft. Zum transdisziplinären Charakter einer Fachwissenschaft, in: Integrative Ansätze in der Geographie - Vorbild oder Trugbild? Münchner Symposium zur Zukunft der Geographie, 28. April 2003. Eine Dokumentation, L.I.S., edited by: Heinritz, G., Passau, 35-52, 2003.

Livingstone, D. N.: Some methodological problems in the history of geographical thought, Tijdschr. Econ. Soc. Ge., 70, 226-231, 1979.

Livingstone, D. N.: The geographical tradition. Episodes in the history of a contested enterprise, Blackwell, Oxford, 1992.

Middell, M. and Naumann, K.: Global history and the spatial turn: from the impact of area studies to the study of critical junctures of globalization, Journal of Global History, 5, 149-170, 2010.

Mitchell, D.: There's no such thing as culture: towards a reconceptualization of the idea of culture in geography, T. I. Brit. Geogr., New Series, 20, 102-106, 1995.

Natter, W. and Wardenga, U.: Die "neue" und die "alte" Cultural Geography in der anglo-amerikanischen Geographie, Berichte zur deutschen Landeskunde, 77, 71-90, 2003.

Nietzsche, F.: Vom Nutzen und Nachteil der Historie für das Leben, Reclam, Stuttgart, 1982/1874.

Philo, C. (Ed.): New words, new worlds: reconceptualising social and cultural geography, St Davids University College, Lampeter, 
Wales, 1991.

Redepenning, M.: Wozu Raum? Systemtheorie, critical geopolitics und raumbezogene Semantiken, Leibniz-Institut für Länderkunde, Leipzig, 2006.

Robic, M.-C., Briend, A.-M., and Rössler, M. (Eds.): Géographes au face du monde, L'Harmattan, Paris, 1996.

Rüsen, J.: Die vier Typen des historischen Erzählens, in: Formen der Geschichtsschreibung, edited by: Koselleck, R., Lutz, H., and Rüsen, J., dtv, München, 514-605, 1982.

Rüsen, J.: Historical Narration: Foundation, Types, Reason, Hist. Theory, 26, Beiheft: The Representation of Historical Events (Dec. 1987), 87-97, 1987.

Schaefer, F. K.: Exceptionalism in geography. A methodological examination, Ann. Ass. Am. Geogr., 43, 226-249, 1953.

Schramke, W.: Zur Paradigmengeschichte der Geographie und ihrer Didaktik. Eine Untersuchung über Geltungsanspruch und Identitätskrise eines Faches, Albrecht, Göttingen, 1979.

Schultz, H.-D.: Die deutschsprachige Geographie von 1800 bis 1970. Ein Beitrag zur Geschichte ihrer Methodologie, Geographisches Institut, Berlin, 1980.

Stoddart, D. R. (Ed.): Geography, ideology and social concern, Blackwell, Oxford, 1981.
Wardenga, U.: Geographie als Chorologie. Zur Genese und Struktur von Alfred Hettners Konstrukt der Geographie, Franz Steiner, Stuttgart, 1995.

Wardenga, U. and Wilczynski, W. (Eds.): Religion, ideology and geographical thought, Instytut Geografii, Kielce, Poland, 1998.

Werner, M. and Zimmermann, B.: Vergleich, Transfer, Verflechtung. Der Ansatz der Histoire croisée und die Herausforderung des Transnationalen, Gesch. Ges., 28, 607-636, 2002.

Werner, M. and Zimmermann, B.: Beyond comparison: histoire croisée and the challenge of reflexivity, Hist. Theory, 45, 30-50, 2006.

Wirth, E.: Zwölf Thesen zur aktuellen Problematik der Länderkunde, Geographische Rundschau, 22, 444-450, 1970.

Wolkersdorfer, G.: Politische Geographie und Geopolitik zwischen Moderne und Postmoderne, Geographisches Institut, Heidelberg, 2001.

Wood, G.: Regionale Geographie im Umbruch? Ansätze einer sozialwissenschaftlichen "New Regional Geography" im angelsächsischen Sprachraum, Berichte zur deutschen Landeskunde, 70, 55-72, 1996. 